\title{
BMJ Open Prevalence and epidemiological characteristics of inmates diagnosed with infectious diseases living in a region with a high number of prisons in São Paulo state, Brazil
}

Charlene Troiani do Nascimento, ${ }^{1}$ Danilo Zangirolami Pena, ${ }^{1}$ Rogério Giuffrida, ${ }^{1}$ Fernanda Nobre Bandeira Monteiro, ${ }^{1}$ Francisco Assis da Silva, ${ }^{1}$ Edilson Ferreira Flores, ${ }^{2}$ Luiz Euribel Prestes-Carneiro (i) ${ }^{1}$

To cite: do Nascimento CT, Pena DZ, Giuffrida R, et al. Prevalence and epidemiological characteristics of inmates diagnosed with infectious diseases living in a region with a high number of prisons in São Paulo state, Brazil. BMJ Open 2020;10:e037045. doi:10.1136/ bmjopen-2020-037045

- Prepublication history for this paper is available online. To view these files, please visit the journal online (http://dx.doi. org/10.1136/bmjopen-2020037045).

Received 16 January 2020

Revised 07 May 2020

Accepted 18 July 2020

Check for updates

(c) Author(s) (or their employer(s)) 2020. Re-use permitted under CC BY-NC. No commercial re-use. See rights and permissions. Published by BMJ.

${ }^{1}$ Postgraduate Department, Master in Health Sciences, Oeste Paulista University, Presidente Prudente, São Paulo, Brazil

${ }^{2}$ Statistics Department, School of Sciences and Technology,

São Paulo State University,

Presidente Prudente, São Paulo, Brazil

Correspondence to

Dr Luiz Euribel Prestes-Carneiro; luiz@unoeste.br

\section{ABSTRACT}

Objective To determine the prevalence and

epidemiological characteristics of inmates diagnosed with infectious diseases living in a region with a high number of prisons, São Paulo, Brazil.

Design This is a retrospective and descriptive study conducted from November 2017 to October 2018.

Setting Prisons located in the western and northwestern regions of São Paulo, Brazil.

Methods We conducted a retrospective analysis on infectious diseases and coinfections (HIV, hepatitis B virus (HBV), hepatitis $\mathrm{C}$ virus (HCV), syphilis and tuberculosis (TB)) of inmates from 28 prisons. Inmates were previously diagnosed following the protocol for control and surveillance of infectious diseases, through laboratory or imaging methods. A questionnaire was completed by the healthcare staff. Prevalence was obtained by dividing the number of individuals with positive results by the number of inmates in each prison. Locations of prisons were obtained and maps were constructed using geographic information systems. Results A total of 741 of 37497 inmates (1.97\%) were diagnosed with HIV, HBV, HCV, syphilis or TB. HIV was the most prevalent infectious disease $(0.68 \%)$, followed by TB $(0.66 \%)$, syphilis $(0.2 \%)$, HCV $(0.2 \%)$ and HBV $(0.04 \%)$. For all of these diseases, prevalence rates varied from very low to high (3.11\% and $2.45 \%$ ) for TB and HIV, respectively, in the five prisons where they were most prevalent. HIV-syphilis was the most associated coinfection (OR, 63.7; 95\% Cl 41.4 to 96.7). Three of those diagnosed with the infection were female and the ratio of female to men was 0.004:1.

Conclusions Our findings demonstrate that the number of cases of infectious disease among inmates in the northwestern and western region of São Paulo is probably underestimated, with lower rates of HCV, HBV and syphilis. This represents a challenge to prisoners' health. Improvements in diagnosis, mainly to reduce viral hepatitis, are crucial with benefits for inmates and the general population.

\section{INTRODUCTION}

The risk of an infectious disease in a prison is higher than in the general population
Strengths and limitations of this study

- The western and northwestern regions of São Paulo state have the highest number of prisons in Brazil, and the risk of infectious diseases in prisoners is higher than that in the general population.

- All individuals who are arrested and sent to a prison unit, and those already incarcerated, are advised on tuberculosis (TB), HIV, hepatitis B virus (HBV), hepatitis $C$ virus (HCV) and syphilis control and surveillance programmes.

- Determination of the prevalence of TB, HIV, HBV, HCV and syphilis may drive future interventions with possible benefits for inmates and the general population.

- The data were obtained through a questionnaire sent to each prison healthcare unit; the prevalence of infections estimated using the questionnaire is not accurate enough.

- Lack of commitment by many units in responding to the questionnaire; therefore, our data came only from those who responded spontaneously, and we were unable to compare the prevalence of infectious diseases between responders and non-responders.

and can be influenced by different factors, including structural and logistic characteristics of prisons and by behavioural habits acquired before or during imprisonment. ${ }^{12}$ However, prisons should provide inmates with access to the public health system to screen for and treat sexually transmitted infectious diseases such as HIV, hepatitis B virus (HBV), hepatitis C virus (HCV) and syphilis and develop effective control and surveillance, including vaccination programs ${ }^{1-3}$ Furthermore, prisons can help to decrease dissemination, especially to inmates' partners. ${ }^{1}$

The number of inmates is increasing worldwide, including in Brazil, with a $707 \%$ 
increase in 2016 since the 1990s. Brazil has the third largest prison population in the world, with 726712 individuals in 1422 facilities and an occupancy rate of $197.4 \%$. São Paulo state has the biggest prison population with 240061 inmates and an occupancy rate of 183\%, representing $33.0 \%$ of inmates countrywide. ${ }^{4}$ The western and northwestern regions have a high number of prisons with 39 units in 2018, housing an estimated 57700 individuals; $80 \%$ of the units are overcrowded. ${ }^{5}$ All prisons are coordinated by the Coordination of Prison Units of Western Region (CROESTE).

The western and northwestern regions of São Paulo state are characterized by small municipalities, mostly with a population of $<20000$ inhabitants. $^{6}$ In contrast to the dynamic economic situation in the rest of the state, sustained growth is hampered by ongoing conflicts between landowners and the Landless Movement (LM). Since its foundation in 1984, LM has been organized around the following objectives: fight for land distribution, fight for agrarian reform and fight for social changes in the country.

Since 1997, to cover the shortage of prisons in the country and the collapse of the penitentiary system, several prisons have been constructed in the region with two main objectives: (1) decentralisation of prisons from the capital São Paulo to country areas and (2) increase the economy and development in the region. However, one of the main questions not yet sufficiently addressed is that, although there is a standard protocol for screening of infectious diseases, what is the prevalence in prisons managed by CROESTE?

There are few studies highlighting the prevalence of infectious diseases of inmates in prisons in São Paulo state. ${ }^{8}$ Our objective was to determine the prevalence and epidemiological characteristics of inmates diagnosed with infectious diseases living in a region with a high number of prisons in the northwestern and western of São Paulo state, Brazil.

\section{METHODS}

\section{Setting and regional characteristics}

São Paulo state, the richest and most populous state of Brazil, is located in the southeastern region and includes 645 municipalities (figure 1A). In June 2019, the state had 173 prisons; in 2018, there were 39 units in the western and northwestern regions under the supervision of CROESTE (figure 1B). ${ }^{5}$ The region covers a large area bordering Mato Grosso do Sul, Minas Gerais and Paraná states. The western region, with an estimated population of 753344 inhabitants in 2018, is considered the second poorest region in the state (figure 1B, yellow). In 1997, to cover the deficit in the country's prison system and the collapse of the penitentiary system, the Federal Government launched a countrywide program for the construction of new prisons. At that time, São Paulo had the largest

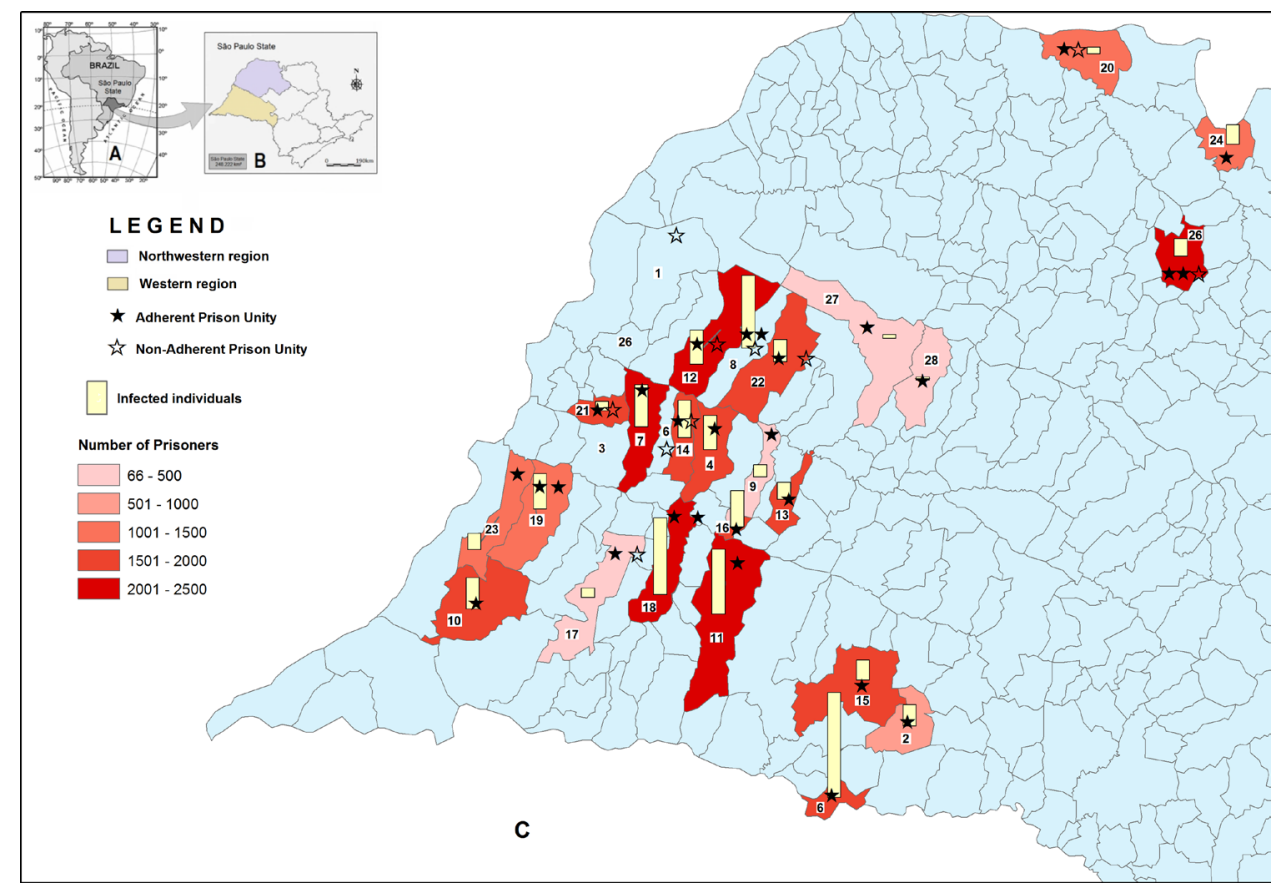

Figure 1 Geospatial location of Brazil and São Paulo state (A), the northwestern and western regions (B) and municipalities where the prisons were constructed (C) 1: Andradina; 2: Assis; 3: Dracena; 4: Flórida paulista; 5: Florínea; 6: Irapuru; 7: Junqueirópolis; 8: Lavínia (three units); 9: Lucelia; 10: Marabá paulista; 11: Martinópolis; 12: Mirandópolis (two units); 13: Osvaldo cruz; 14: Pacaembu; 15: Paraguaçu paulista; 16: Pracinha; 17: Presidente Bernardes; 18: Presidente Prudente; 19: Presidente Venceslau (two units); 20: Riolândia; 21: Tupi paulista (two units); 22: Valparaíso; 23: Caiuá; 24: Icém; 25: nova Independência; 26: São José do Rio Preto; 27: Araçatuba; 28: Birigui. Bars represent the number of cases of infectious diseases in each prison. Colors represent the interval number of inmates in each municipality. Stars represent the number of prisons in each municipality. Current shape file databases and base maps were downloaded from the IBGE website. 
prison population in the country, with a great shortage of penal establishments. ${ }^{9}$ Since 1997, an increasing number of units have been constructed, mainly along the highways linking the bordering states of Mato Grosso do Sul, Minas Gerais and Paraná. ${ }^{5}$

This is a retrospective study conducted from November 2017 to October 2018 on inmates in prisons under the supervision of CROESTE (figure 1C). Of the 39 prisons, with an estimated population of 57700 individuals, 28 prisons (71.8\%) representing 37497 people took part in the study.

\section{Study design}

For infectious diseases, there is a minimum protocol for the diagnosis and the development of actions to promote infection control and surveillance of inmates in prisons in Brazil. ${ }^{10-12}$ At the CROESTE dominium, for people who are arrested and sent to a prison unit, or those incarcerated, the following control programmes are applied. ${ }^{10-13}$

\section{Tuberculosis}

Tuberculosis (TB) control actions are implemented in all penitentiary units. In the search for cases of TB, identify respiratory symptoms; examine individuals with respiratory symptoms using sputum smear microscopy; notify new cases in Brazil's national notification database (Sistema de Informação de Agravos de Notificação (SINAN)); start treatment on a daily supervised basis and offer anti-HIV serology for all diagnosed cases; monthly follow-up of treatment through medical or nursing consultation; perform smear control for cases initially positive. Active searches are performed twice a year, in the first and second semesters. All prison units must have registration books to record respiratory symptoms.

\section{HIV}

Diagnosis should be performed in $100 \%$ of suspected cases. A history of risk, associated clinical manifestations and the presence of opportunistic infections should be investigated. Treatment should be performed in 100\% of diagnosed cases, and condoms distributed to $100 \%$ of inmates. With regard to active searching, following the WHO's global campaign, Red December was introduced and all inmates should be screened for TB and HIV. Those with HIV-positive results are continuously monitored. All diagnosed patients are notified to SINAN.

\section{Viral hepatitis}

Cases of HBV and HCV must be continuously investigated to look for the source of the infection. With regard to active searching, as recommended by the WHO for the Global Fight against Viral Hepatitis, Yellow July was introduced. On this occasion, as well as during active searches for TB and HIV, since 2013, rapid tests for HBV, HCV, HIV and syphilis have been offered.

\section{Syphilis}

The prison system should identify cases of acquired syphilis and in pregnant women to support prevention and control actions of acquired and congenital syphilis. All positive cases must be notified to SINAN. However, the percentage of inmates tested for infectious diseases, especially viral hepatitis and syphilis, varies according to the characteristics and the healthcare staff of each prison unit.

\section{Data collection for each prison unit}

Data was collected using a standard questionnaire sent to the healthcare staff of each prison unit of CROESTE. The questionnaire included epidemiological information: age, gender, schooling, sexual behavior marital status, number of sons, diagnosis of infectious diseases and coinfections (HIV, HBV, HCV, syphilis and TB), treatment and time of incarceration. In each prison unit, the healthcare staff completed the questionnaire only for those who had a confirmed diagnosis by 31 December 2018. Male and female inmates $\geq 18$ years of age were included.

\section{Laboratory methods to screen for infectious diseases in inmates of São Paulo state}

At CROESTE dominium, all laboratory diagnostics are made by the Adolfo Lutz Institute, the public reference laboratory for São Paulo state and by the Laboratory of RH, both in Presidente Prudente, following the protocols of the Brazilian Ministry of Health. ${ }^{10-13}$

\section{Tuberculosis}

Two methods are used to systematically select those more likely to have TB: (1) interview all inmates individually to identify those who cough for $\geq 2$ weeks, regardless of other clinical manifestations, and then carry out diagnostic tests on those identified with respiratory symptoms (Ziehl-Neelsen bacilloscopy/rapid molecular test for TB, culture with species identification with sensitivity tests and imaging examinations); (2) chest X-ray examination, regardless of the existence of symptoms, to identify those who have any type of radiological abnormality (pulmonary, pleural or mediastinal).

\section{HIV}

In the presence of the inmate, the use of rapid tests for the diagnosis of HIV, HBV, HCV and syphilis infection was implemented in 2013, according to the São Paulo State Sexually Transmitted Infections/AIDS Programme. HIV infection is defined with two reagent results in rapid tests (RT1 and RT2) containing different antigens, used sequentially. After two rapid reagent tests, the viral load is assessed, and when positive confirms the presence of the infection. For tests performed on samples obtained by venipuncture, a second sample should be collected to eliminate the possibility of sample exchange. In addition, enzyme immunoassay, western blot, immunoblot (IB) or inline immunoassays, including fast IB could be applied. With positive results, viral load must be assessed.

\section{HBV and HCV}

Since 2013 at CROESTE dominium, HBsAg (HBV surface antigen) can be detected by means of rapid tests. 
When positive, the inmate is referenced to the outpatient medical specialties (OMS) or to the Regional Hospital for the investigation and determination of other HBV markers: total anti-HBc IgM and IgG classes, anti-HBs, HBeAg and anti-HBe as well as HBV-DNA viral load (DNA of HBV). All patients with chronic HBV infection are referred to the tertiary reference centres of OMS or RH for follow-up. Anti-HCV can be detected through the rapid test or laboratory serology for the marker that indicates previous contact with the virus. Anti-HCV positive inmates are referred to OMS or RH for HCV-RNA determination and follow-up.

\section{Syphilis}

Rapid tests allow the detection of specific anti-Treponema pallidum antibodies in serum or whole blood. If the rapid test is positive, blood is collected on the same day and non-treponal tests, Venereal Disease Research Laboratory or rapid plasma reagin, are performed.

\section{Prevalence of infectious diseases in prisons in western São Paulo state}

Countrywide, when a prisoner enters the prison system or during the period of incarceration, there is a minimum protocol for the diagnosis of HIV/STD/AIDS and viral hepatitis. The proportions of infected individuals in each prison were estimated and the $95 \%$ CI were obtained by Wilson's method. A forest plot was constructed to show the increasing order of prevalence for TB and HIV.

\section{Inmates from prison and infected individuals}

A map showing the number of inmates in each prison was created using ArcGIS software V.10.2.2 (ESRI, Redlands, California, USA), using the Symbology-Show Quantiles tool from Layer Properties. Five classes were generated manually at equal intervals. The variable represented the total number of prisoners. The Symbology-Show Charts Bar tool was used to present cases of infectious diseases in columns (white bars). Colours represent the number of inmates in each municipality.

\section{Statistical analysis}

Results are shown as means $\pm \mathrm{SE}$ of the mean (if the variable is normally distributed) and median (IQR) for continuous variables. The association between qualitative variables was assessed using the OR with $95 \% \mathrm{CI}$. The association between HIV positivity and coinfections was evaluated by estimated ORs and 95\% CI. Frequencies and percentages are expressed as dichotomous and nominal variables. The prevalence of infectious diseases was obtained by dividing the number of individuals with positive results by the number of inmates in each prison. Statistical analysis was performed using the GraphPad Software (San Diego, California, USA) and Sigma-Stat program (Systat Software, Richmond, California, USA).

\section{Patient and public involvement statement}

Since our study was a retrospective study, study participants were not involved in the recruitment and conduct of our study design. In addition, no patient advisers were involved. Although the results have not yet been published as a full journal article, copies translated into Portuguese were disseminated to CROESTE as well as to the healthcare staff in each prison unit.

\section{RESULTS}

\section{Prevalence of infectious diseases and coinfections}

Of the 37497 inmates included in the study, 741 (1.97\%) were diagnosed with at least one of the selected diseases and coinfections investigated. The prevalence of HIV was $0.68 \%(\mathrm{n}=256)$, TВ $0.66 \%(\mathrm{n}=247)$, syphilis $0.2 \%(\mathrm{n}=75)$, HCV $0.17 \%(n=65)$, HBV $0.04 \%(n=16)$ and coinfection $0.22 \%(\mathrm{n}=82)$. Three $(0.4 \%)$ of those diagnosed with infection were women (table 1$)$.

\section{Epidemiological characteristics}

The mean age of male inmates was 35.82 years (SD, 10.41 years), ranging from 19 to 91 years (95\% CI 35.06 to 36.58). The mean age of female inmates was 34.0 years (SD, 9.0 years; range, 11.64-56.36 years), and the ratio of women to men was $0.004: 1$. The number of sons was provided for 340 male inmates (mean, 2.47 (SD 1.96); $95 \%$ CI 2.26 to 2.68). The mean number of sons of female inmates was 2.0 (SD 1.73; 95\% CI -2.30 to 6.30 ). The period of incarceration of inmates diagnosed with infectious diseases was available for 706 individuals (95.3\%) (mean, 31.33 months (SD, 50.77 months); 95\% CI 27.58 to 35.08; range, 1-360 months) (table 1).

\section{Association of HIV and coinfections}

Table 2 shows that HIV infection is associated with the presence of TB (OR, 6.4; 95\% CI 3.5 to 11.3 ); HIV infection is also associated with the presence of both $\mathrm{HBV}$ and HCV (OR, 30.9; 95\% CI 19.1 to 48.2); and finally, HIV infection is strongly associated with the presence of syphilis (OR, 63.7; 95\% CI 41.4 to 96.7).

\section{Prevalence and rates of inmates in prison units}

The forest plot (figure 2) shows the name of the city with the number of inmates in ascending order as well as the prevalence and CIs of TB in each unit analysed. In 4 of 28 units $(14.3 \%)$, there were no inmates diagnosed. We calculated the mean level for 5 of $28(17.8 \%)$ units with higher prevalence: Presidente Bernardes 2 of 66 (3.3\%), Presidente Venceslau I 3 of 203 (1.47\%), Presidente Venceslau II 10 of 798 (1.25\%), Martinópolis 41 of 2075 (1.97\%) and Lucélia 9 of 117 (7.6\%), the highest prevalence. The mean $\pm \mathrm{SD}$ for these prison units was $3.11 \pm 2.62$ (95\% CI -0.14 to 6.38 ). Figure 3 shows the name of the city with the number of inmates in ascending order as well as the prevalence and CIs of HIV in each unit. In 2 of 28 units $(7.1 \%)$, there were no inmates diagnosed with HIV. In $18(64.3 \%)$, the levels of inmates infected with HIV showed low variation with moderate levels in 4 (14.3\%) and higher levels in São José do Rio Preto 3 of 184 (1.63\%), Lucélia 2 of 117 (1.70\%), Presidente Prudente I 
Table 1 Clinical, epidemiological characteristics and related to the treatment of infectious diseases and time of incarceration of 741 inmates diagnosed with infectious diseases in prisons in the western and northwestern regions of São Paulo state, Brazil, 2018

\begin{tabular}{|c|c|c|}
\hline \multirow[b]{2}{*}{ Variable } & \multicolumn{2}{|c|}{ Individuals $(n=741)$} \\
\hline & Male, n (\%) & $\begin{array}{l}\text { Female, n } \\
(\%)\end{array}$ \\
\hline \multicolumn{3}{|l|}{ Age } \\
\hline 18-20years & $16(2.16)$ & \\
\hline 21-30 years & $248(33.47)$ & $1(0.13)$ \\
\hline $31-40$ years & $238(32.12)$ & $1(0.13)$ \\
\hline $41-50$ years & $139(18.76)$ & $1(0.13)$ \\
\hline $51-60$ years & $64(8.64)$ & \\
\hline$\geq 61$ years & $9(1.22)$ & \\
\hline Not known & $24(3.24)$ & \\
\hline \multicolumn{3}{|l|}{ Schooling } \\
\hline Illiterate & $19(2.56)$ & \\
\hline Incomplete elementary school & $350(47.24)$ & $1(0.13)$ \\
\hline Complete elementary school & $127(17.14)$ & $1(0.13)$ \\
\hline $\begin{array}{l}\text { Incomplete high school and/or } \\
\text { technical education }\end{array}$ & $123(16.60)$ & \\
\hline $\begin{array}{l}\text { Complete high school and/or } \\
\text { technical education }\end{array}$ & $69(9.32)$ & $1(0.13)$ \\
\hline Incomplete university & $11(1.49)$ & \\
\hline University graduate & $8(1.08)$ & \\
\hline Not known & $31(4.18)$ & \\
\hline \multicolumn{3}{|l|}{ Sexual behaviour } \\
\hline Heterosexual & $567(76.52)$ & $3(0.39)$ \\
\hline Homoaffective & $88(11.88)$ & \\
\hline Bisexual & $33(4.46)$ & \\
\hline Not known & $50(6.75)$ & \\
\hline \multicolumn{3}{|l|}{ Marital status } \\
\hline Single & $336(45.35)$ & $1(0.13)$ \\
\hline Married & $305(41.16)$ & \\
\hline Divorced & $53(7.16)$ & $1(0.13)$ \\
\hline Widow & $15(2.03)$ & $1(0.13)$ \\
\hline Not informed & 29 (3.91) & \\
\hline \multicolumn{3}{|l|}{ Number of sons } \\
\hline None & 285 (38.46) & \\
\hline $1-2$ & 219 (29.57) & $3(0.39)$ \\
\hline $3-4$ & 86 (11.61) & \\
\hline$\geq 5$ & $32(4.32)$ & \\
\hline Not known & $116(15.65)$ & \\
\hline \multicolumn{3}{|l|}{ Treatment } \\
\hline Never treated & $73(9.61)$ & \\
\hline Abandoned treatment & $14(1.84)$ & \\
\hline Complete treatment & $99(13.02)$ & \\
\hline
\end{tabular}

Continued
Table 1 Continued

\begin{tabular}{lcl} 
Variable & Male, n (\%) & (\%) \\
\hline Treatment up to 2000 & $29(3.81)$ & $1(0.13)$ \\
Treatment 2001-2010 & $63(8.29)$ & \\
Treatment since 2011 & $464(61.06)$ & $2(0.26)$ \\
Not known & $15(1.98)$ & \\
How long incarcerated & & \\
$<$ 1 year & $319(43.07)$ & $3(0.39)$ \\
1-5years & $297(40.08)$ & \\
6-10years & $48(6.48)$ & \\
11-20years & $32(4.32)$ & \\
$>$ 20years & $17(2.29)$ & \\
Not known & $25(3.37)$ & \\
Imprisonment & & \\
First & $179(24.17)$ & $3(0.39)$ \\
\hline Previous & $429(57.90)$ & \\
Not known & $130(17.54)$ & \\
\hline
\end{tabular}

48 of 1938 (2.47), Presidente Bernardes 1 of 66 (1.51\%) and Florínea 56 of $1707(3.28 \%)$ with the highest prevalence. Presidente Bernardes and Lucélia showed a higher prevalence of both TB and HIV.

Figure $1 \mathrm{C}$ shows that the number of inmates by prison varied from low (66-500) in 4 prisons to high (1501$2500)$ in 12 prisons $(42.9 \%)$. Four municipalities had two prisons and one had three prisons.

\section{DISCUSSION}

Most Brazilian studies on infectious diseases in prisons were conducted in just one or in a few units. ${ }^{14}{ }^{15}$ HIV was the most prevalent infectious disease diagnosed with prevalence rates of $0.68 \%$, lower than the $1.3 \%$ suggested by countrywide national data. ${ }^{16}$ In the western region, all inmates diagnosed with HIV are treated and are followed by specialists in reference centres in Presidente Prudente. ${ }^{17} 18$ Prevalence of $1.8 \%$ was detected in a prison in São Paulo state. ${ }^{8}$ In a prospective study of 3362 inmates from 12 prisons in the central-west region of Brazil in 2013, a prevalence of $1.6 \%$ was found..$^{14}$ However, Dolan et $a l^{19}$ reported that an estimated 10.2 million people are incarcerated worldwide and $3.8 \%$ are living with HIV. In Latin America, prevalence varies from $1.5 \%$ to $5 \%$. When the mean level of 5 units was calculated, the prevalence was $3.11 \%$, higher than state-wide levels $(1.8 \%)^{8}$ and countrywide levels $(1.3 \%),{ }^{16}$ but similar to the levels found for prisons in Latin America $( \pm 3.0 \%)$ and worldwide $(3.8 \%){ }^{19}$ This result highlights that despite the efforts of public health policies for screening HIV in prisons of São Paulo state, particularly at CROESTE dominium, in the other 23 units, there is an important 
Table 2 Association between HIV and coinfections in 741 prison inmates in the western and northwestern regions of São Paulo state, Brazil, 2018

\begin{tabular}{|c|c|c|c|c|c|c|}
\hline \multirow[b]{2}{*}{ Disease } & \multicolumn{3}{|l|}{ HIV } & \multirow[b]{2}{*}{ OR } & \multirow[b]{2}{*}{$95 \% \mathrm{Cl}$} & \multirow[b]{2}{*}{$P$ value } \\
\hline & Positive, n (\%) & Negative, n (\%) & Total, n (\%) & & & \\
\hline \multicolumn{7}{|l|}{ Hepatitis } \\
\hline Negative & $303(0.81)$ & 37060 (98.83) & 37363 (99.64) & & & \\
\hline Total & $330(0.88)$ & 37167 (99.12) & $37497(100.0)$ & & & \\
\hline \multicolumn{7}{|l|}{ Tuberculosis } \\
\hline Positive & $14(0.04)$ & $252(0.67)$ & $266(0.71)$ & 6.4 & 3.5 to 11.3 & $<0.001$ \\
\hline Negative & $316(0.84)$ & 36915 (98.45) & 37231 (99.29) & & & \\
\hline Total & $330(0.88)$ & 37167 (99.12) & $37497(100.00)$ & & & \\
\hline \multicolumn{7}{|l|}{ Syphilis } \\
\hline Positive & $39(0.10)$ & $78(0.21)$ & $117(0.31)$ & 63.7 & 41.4 to 96.7 & $<0.001$ \\
\hline
\end{tabular}

P, statistical significance for the hypothesis that OR differs statistically from 0 .

lack of HIV diagnosis. This is highlighted by the fact that in two prisons, Presidente Prudente II and Mirandópolis, no inmates were diagnosed with HIV.

TB ranked second with a prevalence of $0.7 \%$, similar to the $0.9 \%$ found in prisons countrywide. ${ }^{16}$ However, when the mean for the five prisons units with a higher prevalence of inmates infected with TB was calculated, the prevalence of $3.11 \%$ was found. Since the discovery of HIV, the concept of double-trouble for HIV-TB coinfection highlights the interlinked issues. Prisons act as incubators for these agents because they are associated with higher levels of infection than in the surrounding population. ${ }^{1920}$ In Brazil, the incidence coefficient of
TB decreased from 42.7 cases per 100000 inhabitants in 2001 to 34.2 in $2014 .{ }^{11}$ Conversely, countrywide there was an overwhelming increase in TB rates in prisons. ${ }^{12}$ In a survey carried out for the national notification database, in 2009-2014, TB cases among prisoners increased by $28.8 \% .^{21}$ Corroborating these data, in the 12 prisons in the central-west region, a prevalence of $0.7 \%$ was found at baseline and $1.8 \%$ 1 year later. ${ }^{14}$ At the regional level, there is little data on São Paulo state. In 2008, an observational study on 2435 inmates in one prison and one jail in the city of Guarulhos, in the metropolitan area of São Paulo, a prevalence of $0.83 \%$ was found. ${ }^{22}$ Thus, the prevalence in these studies was similar to our data,

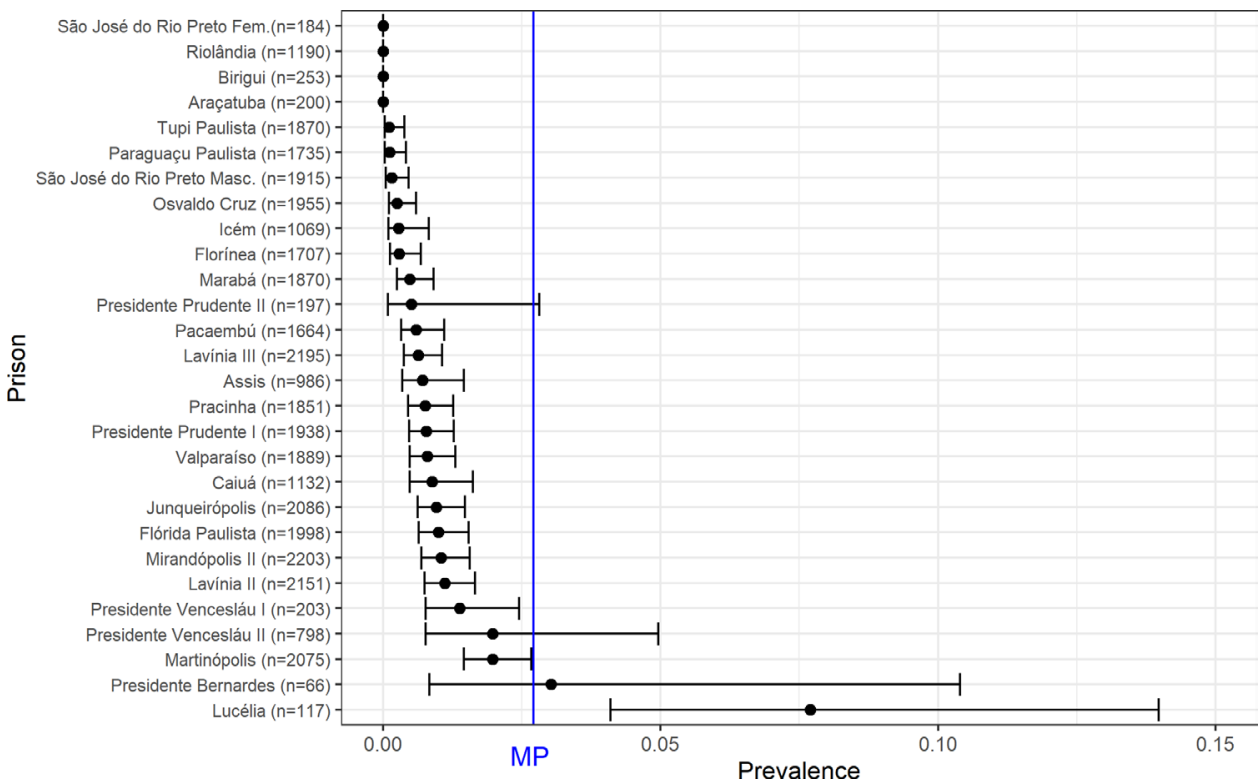

Figure 2 Forest plot for prevalence estimates of inmates diagnosed with TB in prisons located in the western and northwestern region of São Paulo state. MP, mean prevalence. 


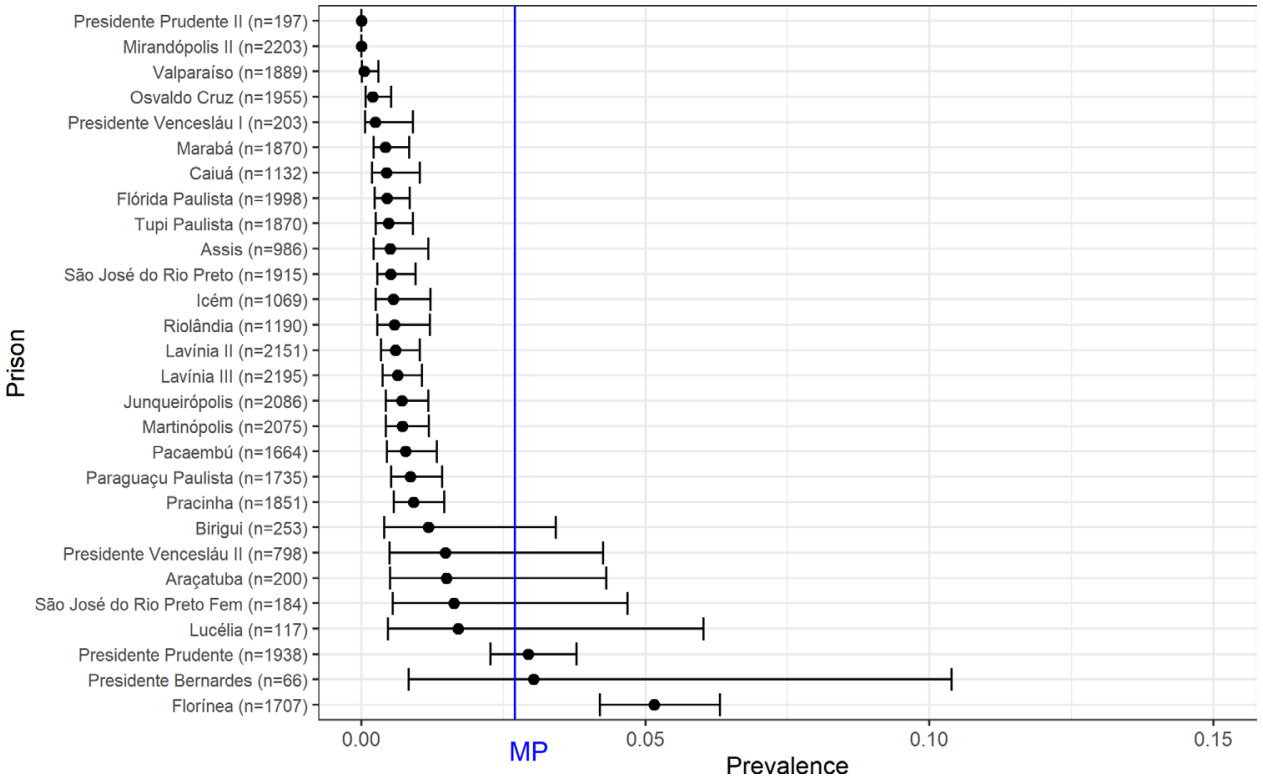

demonstrating the efforts of public health policies for screening TB in São Paulo state, particularly at CROESTE dominium. However, higher levels $(3.11 \%)$ than statewide and countrywide were found in five prison units. In Lucélia, a prevalence rate of $7.6 \%$ was found. Conversely, in four prisons units, no inmates infected with TB were found. In both cases, regional and local measures should be taken urgently to determine why TB is spreading in Lucélia, and why no patients were found to have TB in São José do Rio Preto, Riolândia, Birigui and Araçatuba. In these settings, it is possible that the burden of TB cases at the population level is underestimated.

In this study, patients with were more likely to be coinfected with other diseases. Of 82 individuals who had a coinfection, only $1.08 \%$ did not present HIV. The OR for HIV patients coinfected with TB was 6.4. Worldwide, compared with the general population, people living with HIV/AIDS are 26 times more likely to develop active TB, and in Brazil, this risk is 28 times higher, quite different from the rates found in the studied population. ${ }^{23}$ The data demonstrate the overwhelming need to increase the search for patients with HIV-TB coinfection in prisons in the CROESTE domain.

HBV and HCV are serious global public health problems characterized by chronic infections that may not show symptoms for a long period, sometimes years or decades. ${ }^{24}$ In this study, the prevalence of HCV and HBV was $0.2 \%$ and $0.04 \%$, respectively, lower than the $0.6 \%$ found in prisons countrywide for both $\mathrm{HBV}$ and $\mathrm{HCV} .^{16}$ The prevalence of HCV in inmates is similar to that in the general population (estimated to be $0.7 \%$ in 2017). ${ }^{23}$ In $2013,15.1 \%$ and $4.8 \%$ of the worldwide incarcerated population had HCV and chronic HBV infection. ${ }^{19}$ In 2007, a cross-sectional study conducted in a prison in São Paulo reported that the prevalence of $\mathrm{HBV}$ and $\mathrm{HCV}$ was $21.0 \%$ and $5.3 \%$, respectively, ${ }^{8}$ similar to $18.9 \%$ and $6.1 \%$ obtained in women incarcerated in the largest prison in Goiás state, central Brazil. ${ }^{25}$ Our rates are about 80 -fold lower than the global and local prevalence of HBV and HCV. The association of people living with HIV coinfected with viral hepatitis showed an OR of 30.9. Countrywide, from 2007 to $2017,9.4 \%$ of the total number of cases of HCV and $5.2 \%$ of cases of HBV were coinfected with HIV, different from the $0.06 \%$ and $0.04 \%$ for HIVHCV and HIV-HBV, respectively, found in this study. In Brazil, the risk of HIV-infected individuals acquiring HCV is 51 times higher than in the general population. ${ }^{23}$

Syphilis, a bacterial infection caused by T. pallidum, results in substantial morbidity and mortality. Syphilis is a sexually transmitted infection (STI) usually spread through contact with infectious sores on the genitals, anus, rectum, lips or mouth, via blood transfusion, or through mother-to-child transmission during pregnancy. ${ }^{26}$ In this study, syphilis ranked third with a prevalence of $0.2 \%, 2.5-$ fold lower than the national data for inmates $(0.5 \%){ }^{16}$ In São Paulo state, in 2003 the prevalence of T. pallidum in Ribeirão Preto Penitentiary was $3.0 \% .{ }^{27}$ In 2007, in a prospective study among 680 individuals in a prison in São Paulo city, the prevalence was $5.3 \%{ }^{8}$ In a prospective study conducted in 12 prisons in central-west Brazil, the prevalence was $9.4 \% .{ }^{14}$ In a retrospective analysis using a methodology similar to our study, at the Regional Prison of Santa Cruz do Sul, Rio Grande do Sul, a prevalence of $6 \%$ was found. ${ }^{28}$ Our data are about 15 -fold and 26-fold lower than in the studies conducted in São Paulo state, suggesting that similarly to HIV and viral hepatitis, the disease is underdiagnosed with serious implications for public health. Women visitors are at high risk for HIV/ syphilis infection from their partners and most of them are not aware and underestimate their risk. ${ }^{29}$ In this study, the OR for HIV patients coinfected with syphilis was 63.7, a higher OR among the coinfections. The countrywide 
prevalence of HIV-syphilis coinfection is not known, because there are no coinfection data in the notification and investigation records on acquired syphilis or HIV/ AIDS in the SINAN.

The lower prevalence rates of HBV, HCV and syphilis in this study compared with the countrywide rates and the rates in São Paulo state may reflect the difficulties in screening infectious diseases and executing the protocol proposed by the health regulatory agencies of Brazil, particularly in the CROESTE dominium. ${ }^{10-13}$ Different factors may be implicated, including omission and incorrect information given by the healthcare staff responsible for completing the questionnaire; deficient numbers of healthcare professionals and their continuous turnover, with discontinuation of the active search programmes in the prisons; difficulties in assessing diagnosis and treatment because there are no doctors available in some units and inmates must go to hospitals, healthcare or reference centres. In this scenario, a high-security operation is necessary. This is also referred by healthcare workers from maximum security penitentiaries where it is necessary to follow the prisoner from their cell to the ward; inefficient communication from the prisons about the diagnosis of infectious diseases and information lost when the inmate is transferred from one unit to another. Taken together, these results reflect the percentage of inmates not yet linked to care, especially for HBV and HCV, which represent a threat to the eradication of HCV. Furthermore, the lack of data about the percentage of tested inmates for viral hepatitis shows the fragility of the results found, because prevalence depends highly on how many inmates are tested, which varies within prisons. Guided by the WHO, in 2016, the Global Health Sector Strategy on viral hepatitis called for its elimination as a major public health threat by 2030 (ie, $90 \%$ reduction in incidence and $65 \%$ in mortality). In recent years, with the introduction of new direct-acting antivirals (DAAs) the treatment scenario has changed significantly in prisons worldwide. ${ }^{30}$ The short duration of the therapy, low numbers or singlepill regimens, low side effects and mainly the high levels of patients achieving a sustained virological response with no detectable RNA in 12 weeks or more after treatment were the main goals. At CROESTE dominium, with the advent of DAAs, a growing number of inmates are receiving treatment for $\mathrm{HCV}$.

With respect to the age group, $65.9 \%$ of the infected individuals were between 21 and 40 years old. It is well known that in this period, men and women are most susceptible to STIs. ${ }^{14}$ In this study, $50.0 \%$ failed to complete elementary school, showing that low schooling is a risk factor for being arrested and acquiring infectious diseases. ${ }^{14}$ Most inmates (76.9\%) self-denominated as heterosexual; however, it is well known that for different reasons, there is promiscuity in prisons. This number is probably overestimated; many are bisexual, highlighted by the fact that countrywide, $60 \%$ of inmates had single civil status. ${ }^{4}$ The number who received treatment for the diseases investigated in this study was significantly higher than those who did not, mainly due to the Brazilian Ministry of Health's TB and HIV Surveillance and Control Programmes. In our study, $57.9 \%$ had been in prison previously, favouring the possibility of primary infection or reinfection, especially of TB. Worldwide, prison healthcare is currently deficient in the continuity of care.${ }^{19}$ In the region, a high number of prisons have great variation in the number of inmates, from just 66 to 2500 individuals (figure 1C). Although there is a protocol to be followed statewide for the active search for infectious diseases in prisons, the diagnosis depends in part on the implementation and attitude of the healthcare staff in each unit.

\section{Limitations of the study}

Some shortcomings must be highlighted in our study. There was a lack of commitment by many units in responding to the questionnaire; therefore, our data come only from those who responded spontaneously, and we were unable to compare the prevalence of infectious diseases in responders and non-responders. Long distances between prisons made access difficult and expensive. The determination of the prevalence of infectious diseases estimated using the questionnaire is not accurate enough. Rapid tests for screening viral hepatitis and syphilis were implemented only in 2013, and the difficulties in serological diagnosis may be one of the reasons for lower prevalence rates of HBV, HCV and syphilis. Only three of $741(0.4 \%)$ of those diagnosed with an infection were female and the sample is too small to speculate about a gender difference in infectious diseases.

\section{CONCLUSIONS}

Our findings demonstrate that the number of cases of infectious diseases among inmates in the northwestern and western region of São Paulo state is probably underestimated, with lower rates of HCV, HBV and syphilis; this presents a challenge to prisoners' health. Improvements in diagnosis to reduce mainly viral hepatitis are crucial with benefits for inmates and the general population.

Acknowledgements The authors thank Roberto Medina and Denise Yukiko Tomokane for the support of data collection in each prison unit.

Contributors CTN: collection, tabulation, study design and writing of the manuscript; DZP: tabulation; EFF, RG, FNB, FAS: geospatial statistics; LEP-C: drafting and critical review of the manuscript.

Funding This work was funded by UNOESTE (grant no. CPDI 4088).

Map disclaimer The depiction of boundaries on this map does not imply the expression of any opinion whatsoever on the part of $B M J$ (or any member of its group) concerning the legal status of any country, territory, jurisdiction or area or of its authorities. This map is provided without any warranty of any kind, either express or implied.

\section{Competing interests None declared.}

Patient consent for publication Not required.

Ethics approval All procedures performed in studies involving participating human subjects were done in accordance with the ethical standards of the institution and/or National Research Committee and with the declaration of 1964 Helsinki Conference and its subsequent amendments or comparable ethical standards. This study was approved by the Ethics Committee of Oeste Paulista University (protocol number CAAE 73092117.1.0000.5515 CPDI 4088) and by the Ethics Committee 
of Public Security Secretary of São Paulo state (protocol number 2.639.635). As a retrospective and descriptive study that dispensed with the collection of direct information from the research participants, the waiver of the Informed Consent was approved by the Ethics Committee of Public Security Secretary of São Paulo state.

Provenance and peer review Not commissioned; externally peer reviewed.

Data availability statement № data is available. The data are not publicly available because they contain information that could compromise the security of the prison system of CROESTE.

Open access This is an open access article distributed in accordance with the Creative Commons Attribution Non Commercial (CC BY-NC 4.0) license, which permits others to distribute, remix, adapt, build upon this work non-commercially, and license their derivative works on different terms, provided the original work is properly cited, appropriate credit is given, any changes made indicated, and the use is non-commercial. See: http://creativecommons.org/licenses/by-nc/4.0/.

ORCID iD

Luiz Euribel Prestes-Carneiro http://orcid.org/0000-0002-4577-1525

\section{REFERENCES}

1 Sequera V-G, Valencia S, García-Basteiro AL, et al. Vaccinations in prisons: a shot in the arm for community health. Hum Vaccin Immunother 2015;11:2615-26.

2 Sequera VG, Bayas JM. [Vaccination in the prison population: a review]. Rev Esp Sanid Penit 2012;14:99.

3 Iroh PA, Mayo H, Nijhawan AE. The HIV care cascade before, during, and after incarceration: a systematic review and data synthesis. Am J Public Health 2015;105:e5-16.

4 Ministry of Justice and Public Security. National survey of penitentiary information: INFOPEN. National Penitentiary Department, 2017: 1-65.

5 Secretariat of Penitentiary Administration. Coordination. prison units. Available: <http://www.sap.sp.gov.br/uni-prisionais-reg/cro.html\#> [Accessed 26 Oct 2019].

6 Ibge. Brazilian Institute of geography and statistics. Rio de Janeiro. Available: <https://cidades.ibge.gov.br/brasil/sp/sao-paulo/ panorama [Accessed 30 Oct 2019].

7 Prestes-Carneiro LE, Rubinsky-Elefant G, Ferreira AW, et al. Seroprevalence of toxoplasmosis, toxocariasis and cysticercosis in a rural settlement, São Paulo state, Brazil. Pathog Glob Health 2013;107:88-95.

8 El Maerrawi I, Carvalho HB. Prevalence and risk factors associated with HIV infection, hepatitis and syphilis in a state prison of São Paulo. Int J STD AIDS 2015;26:120-7.

9 Ministry of Justice Brazil. National Council of criminal and penitentiary policyCensus of the penitentiary of 1995. 2 ed. Brasília: Ministry of Justice, 1997.

10 Department of Surveillance Brazil. Prevention and control of sexually transmitted infections of HIVIAIDS and viral hepatitis. technical manual for the diagnosis of HIV infection in adults and children / Ministry of health, Secretariat of health surveillance, department of surveillance, prevention and control of sexually transmitted infections, HIVIAIDS and viral hepatitis. Brasilia: Ministry of Health, 2016: 1-149.

11 Ministry of Health Brazil, Department of health surveillance, Department of STD, AIDS and viral hepatitis. The technical manual for the diagnosis of viral hepatitis. Brasilia: Ministry of Health, 2015: 1-68.

12 Ministry of Health Brazil. Health Surveillance Secretariat. Portal Tuberculosis: what is it, causes, symptoms, treatment, diagnosis and prevention. Available: <http://portalms.saude.gov.br/saude-de-a-z/ tuberculose [Accessed 28 Jan 2019].

13 Department of Surveillance Brazil. Prevention and control of sexually transmitted diseases, AIDS and viral hepatitis. technical manual for diagnosis of syphilis / Ministry of health, department of health surveillance. Brasília: Ministry of Health, 2016: 1-52.

14 Sgarbi RVE, Carbone AdaSS, Paião DSG, et al. A cross-sectional survey of HIV testing and prevalence in twelve Brazilian correctional facilities. PLoS One 2015;10:e0139487.

15 Nascimento MAFdo, Uziel AP, Hernández JdeG. Young men in juvenile detention centers in Rio de Janeiro, Brazil: gender, sexuality, masculinity and health implications. Cad Saude Publica 2018;34:e00177916.

16 Ministry of justice Brazil, National Secretariat of justice, National Penitentiary Department. National survey of penitentiary information INFOPEN, 2014. Available: https://www.conjur.com.br/dl/infopendez14.pdf [Accessed 26 Oct 2018].

17 Portelinha Filho AM, Nascimento CUdo, Tannouri TN, et al. Seroprevalence of HBV, HCV and HIV co-infection in selected individuals from state of São Paulo, Brazil. Mem Inst Oswaldo Cruz 2009;104:960-3.

18 Prestes-Carneiro LE, Vieira JTM, Isaac LB, et al. Clinical, demographic, and epidemiologic characteristics of hepatitis $B$ virus-infected patients at a tertiary public hospital in Presidente Prudente, state of São Paulo, Brazil. Rev Soc Bras Med Trop 2016;49:24-8.

19 Dolan K, Wirtz AL, Moazen B, et al. Global burden of HIV, viral hepatitis, and tuberculosis in prisoners and detainees. Lancet 2016;388:1089-102.

20 Altice FL, Azbel L, Stone J, et al. The perfect storm: incarceration and the high-risk environment perpetuating transmission of HIV, hepatitis $C$ virus, and tuberculosis in eastern Europe and central Asia. Lancet 2016;388:1228-48.

21 Bourdillon PM, Gonçalves CCM, Pelissari DM, et al. Increase in Tuberculosis Cases among Prisoners, Brazil, 2009-2014. Emerg Infect Dis 2017;23:496-9.

22 Nogueira PA, Abrahão RMCdeM, Galesi VMN. Tuberculosis and latent tuberculosis in prison inmates. Rev Saude Publica 2012;46:119-27.

23 Ministry of health Brazil, Department of Health Surveillance. Epidemiological Bulletin. Brasília: Ministry of Health, 2018: 49. 1-18.

24 World Health Organization. World hepatitis day, 2018. Available: https://www.who.int/campaigns/world-hepatitis-day/2018 [Accessed 30 May 2019].

25 Barros LAS, Pessoni GC, Teles SA, et al. Epidemiology of the viral hepatitis $B$ and $C$ in female prisoners of metropolitan regional prison complex in the state of Goiás, central Brazil. Rev Soc Bras Med Trop 2013;46:24-9.

26 Paho. Pan American health organization. sexually transmitted infections, syphilis. Available: https://www.paho.org/hq/index.php? option=com_content\&view=article\&id=14869:sti-syphilis\&ltemid= 3670\&lang=en [Accessed 21 Apr 2020].

27 Coelho HC, Passos ADC. Low prevalence of syphilis in Brazilian inmates. Braz J Infect Dis 2011;15:94-5.

28 Machado F, Becker D, Oliveira CF, et al. Seroprevalence of HIV, hepatitis $B$ and $C$ and syphilis infection in prisoners of the central region of Rio grande do Sul, Brazi. O mundo da Saúde 2019:117-28.

29 Grinstead OA, Zack B, Faigeles B. Collaborative research to prevent HIV among male prison inmates and their female partners. Health Educ Behav 1999;26:225-38.

30 Pontali E, Fiore V, lalungo AM, et al. Treatment with direct-acting antivirals in a multicenter cohort of HCV-infected inmates in Italy. Int J Drug Policy 2018;59:50-3. 